\title{
Exchange Rate Modeling under Unconventional Monetary Policy on a European Panel Sample
}

\author{
Gábor Dávid Kiss - Mercédesz Mészáros*
}

\begin{abstract}
:
Following the latest subprime crisis, central banks introduced several unconventional instruments which had spillover effects on foreign exchange rates. The aim of our paper is to explore whether the use of zero lower bound (ZLB) and unconventional instruments has an impact on the changes in foreign exchange rates. By running dynamic panel regressions, we analysed this issue on a sample of 7 European central banks.

Based on our results, unconventional monetary policy had a significant impact on the exchange rate fluctuations in the short term, even with the use of instruments where there was no targeted exchange rate regulation.
\end{abstract}

Key words: interest rate parity; unconventional monetary policy; panel regression.

JEL classification: E52, E58, E43, C33

\section{Introduction}

Currently there is apparent tightening and exit from unconventional monetary policy as the elevated policy rates and the end of asset purchase programs became common among main central banks. These unconventional instruments were introduced after central banks were not able to cut the key policy rates further and they had to expand their balance sheets to fight deflation and restore financial stability. However, these policy changes raised additional international spillovers with turbulent capital flows. For example, the Swiss and Czech currencies suffered from excessive appreciation and the Hungarian forint depreciated dramatically as the European Central Bank (ECB) demonstrated deeper commitment towards the quantitative easing $(\mathrm{QE})$.

This paper focuses on the potential impacts on the currency markets through dynamic panel regressions which extend the mainstream interest rate parity with excessive capital flows and the unconventional monetary instruments on a sample of five non-euro EU Member States and Switzerland. This agenda requires

\footnotetext{
Gábor Dávid Kiss; University of Szeged, Faculty of Economics and Business Administration, <kiss.gabor.david@eco.u-szeged.hu>.

Mercédesz Mészáros; University of Szeged, Faculty of Economics and Business Administration, <mercedesz.mszrs@gmail.com>.

The article is processed as an output of a research project supported by the UNKP-18-2 New National Excellence Program of the Ministry of Human Capacities.
} 
Kiss, G. D. - Mészáros, M.: Exchange Rate Modeling under Unconventional Monetary Policy.

identification of the exact application of each unconventional instrument and an extension of the standard uncovered interest rate parity with them, following certain back testing with other macro variables which can be relevant for the transmission mechanism. Activities related to unconventional instruments, have their footprint on the central banks' balance sheets, as the theoretical background section will present. This analysis can be motivated by the fact that now, at the possible end of $\mathrm{QE}$, it is possible to test the entire eleven yearlong quarterly dataset (from 2007 Q1 to 2018 Q1). The sample covers the ECB and central banks of open and small economies like Czechia, Denmark, Hungary, Poland, Sweden and Switzerland. Three subsets were created to represent the differences in monetary policies, capital flows and exchange rate movements: a safe haven (with Denmark and Switzerland), Visegrad-3 (with Czechia, Hungary and Poland) and QE (with Sweden and the ECB).

This study is structured as follows: the second section summarises the theoretical background of exchange rate movements, introduces unconventional monetary policy instruments and theoretical models which will be the subjects of further analysis. The third section presents the analysed dataset and the summary of dynamic panel regressions, while the fourth part contains the results of the model testing.

\section{Theoretical Background}

This section summarises the main theoretical approaches to describe currency fluctuations, introduces the different unconventional instruments and categorises their application in the sample. Theoretical models are the synthesis of these two subsections.

\subsection{Exchange rate movements}

Exchange rates can be managed directly via peg-like regimes or indirectly under the floating-like approaches. Non-euro countries are maintaining independent floating regimes under liberalised capital flows to meet Mundell-Fleming trilemma and to maintain some sort of autonomy. The uncovered interest parity (1) describes foreign exchange rate changes $\left(\Delta e_{t}\right)$ by the differentials in their interest rates $(r)$ on a well-performing market (Herger, 2016; MNB, 2012):

$$
\Delta e_{t}=\omega+\alpha \Delta\left(r_{t, d}-r_{t, f}\right)+\varepsilon_{t}
$$

Foreign exchange rates (FX) are channelled in the transmission mechanism due to their impact on domestic prices. However, open and small economies are affected by FX changes much more and even the prime policy rate is influenced as it is represented in the specific Taylor-rule - partially it can be responsible for the "fear of floating" behaviour as well (Calvo and Reinhart, 2002; Svensson, 2000; Taylor, 2001; Taylor, 1993). 
Flight to safety can bias currency markets due to a sudden and excessive demand for safe assets $^{1}$ - especially when their range decreases due to the market sentiment changes (Bekaert et al., 2009; Horváth and Szini, 2015). The Great Financial Crisis (GFC) initiated such a flight with sudden stops for riskier emerging countries (Kiss and Szilágyi, 2014; Pelle and Végh, 2019) - which can be captured in the portfolio investment changes. Safe haven currencies (like CHF) faced (and still facing) appreciation pressures which were motivated mainly by the capital inflows instead of interest premia $\left(r_{t, d}-r_{t, f}>0\right)$ (Ranaldo and Söderlind, 2010; Habib and Stracca 2012). Flight to safety can be a disruptive sign of how limited is the monetary autonomy of the safe havens: for example, the Swiss central bank was not able to withstand the appreciation pressure regardless their efforts to introduce a negative interest premium, the inflation of their FX reserves and the introduction of a temporary FX ceiling. These theoretical results are pointing towards the inclusion of the capital inflows (namely the balance of portfolio investments $-P F$ ) in the conventional model of uncovered interest rate parity (2) and a dummy $(D)$ variable to represent the introduction and maintenance of temporary peg-like measures (Model I.):

$$
\Delta e_{t}=\omega+\alpha \Delta e_{t-1}+\beta_{1} \Delta\left(r_{t, d}-r_{t, f}\right)+\beta_{2} \Delta P F_{t}+\beta_{5} D_{t}+\varepsilon_{t}
$$

\subsection{Unconventional monetary instruments}

The asset side of the central bank balance sheet (CBBS) can be approximated by a sum (3) of FX reserves $\left(F X_{t}\right)$, loans to the domestic banking system $\left(L_{t}\right)$ and accumulated securities $\left(S_{t}\right)$ with dominance of the reserves:

$$
C B B S_{t}=S_{t}+L_{t}+F X_{t} \text {, where } F X_{t}>S_{t}+L_{t} .
$$

The introduction of unconventional monetary policies were the response to the bursts of deflationary waves and deteriorating financial stability during the GFC with instruments focusing on zero interest rates (zero lower bound, ZLB), longterm lending, asset purchases of even currency swap agreements. These instruments were combined into programs to enhance the transmission mechanism, smooth the yield curve or reduce a specific asset's risk premium (Krekó et al., 2012; Csortos et al., 2014).

ZLB was mainly combined with forward guidance to anchor expectations and QE initiates lending or security programs which have structural and size impacts on the central bank balance sheet. The expansion and recombination (4) of the asset side changes the usual FX reserve based CBBS - referred to later as "LSFX (Bernanke and Reinhart, 2004; Czeczeli, 2017; Kool and Thornton, 2012):

\footnotetext{
${ }^{1}$ Investors would feel comfortable using them as a "store of value" (Beckworth 2011).
} 
Kiss, G. D. - Mészáros, M.: Exchange Rate Modeling under Unconventional Monetary Policy.

$$
\Delta C B B S_{t}>0 \text {, under } \mathrm{QE} \text { leads to } \Delta \frac{L_{t}+S_{t}}{F X_{t}}>0 .
$$

A detailed analysis was obtained on the sample central banks, to check the application of various unconventional monetary instruments and to see, what kind of discretionary FX regimes were introduced against the excessive appreciation (FX ceiling) and a summary about the balance of portfolio investments in the analysed period (Tab. 1). There were common instruments like forward guidance, FX swaps or negative interest policy, while asset purchase programs were important mainly for the ECB, SR and later for the MNB. While Swiss and Danish CBs were faced with a positive portfolio investment balance, the Swedish CB or the ECB experienced a balanced situation. V3 countries suffered from the withdrawal of the portfolio investments. Denmark followed a tight peg since the 1990s, while Switzerland adopted an upper ceiling between 2012 and 2015, and Czechia maintained a similar regime between 2013 and 2017.

Tab. 1: The application of unconventional instruments (2007-2018)

\begin{tabular}{|c|c|c|c|c|c|c|c|}
\hline $\begin{array}{l}\text { instrumentlcentral } \\
\text { bank }\end{array}$ & MNB & NBP & CNB & SNB & DN & SR & ECB \\
\hline asset purchase programs & - & & & & & - & - \\
\hline forward guidance & - & - & - & - & - & - & - \\
\hline negative interests & - & & & - & - & - & - \\
\hline $\begin{array}{l}\text { quantity limits on } \\
\text { refinancing }\end{array}$ & - & • & & - & • & $\bullet$ & \\
\hline FX swap & $\bullet$ & • & $\bullet$ & $\bullet$ & - & $\bullet$ & $\bullet$ \\
\hline interest swap & - & & & & & & \\
\hline targeted lending & - & & & & & & - \\
\hline FX ceiling & & & $\bullet$ & $\bullet$ & & & \\
\hline $\begin{array}{l}\text { asymmetric interest } \\
\text { channel }\end{array}$ & $\bullet$ & & • & & & & $\bullet$ \\
\hline PF balance & - & - & - & + & + & $+/-$ & $+/-$ \\
\hline FX regulations & $x$ & $x$ & $\checkmark$ & $\checkmark$ & $\checkmark$ & $x$ & $x$ \\
\hline
\end{tabular}

Source: authors' computation, based on the CBs' press releases after monetary council meetings

These results are supporting Singer's (2015) results, who suggested the application of liquidity-oriented instruments and forward guidance at the key central banks (US FED; ECB and Bank of Japan). These recovery programs were efficient according to Gambacorta et al. (2014) or Lewis and Roth (2015), but such interventions presented their results slower and they required higher efforts (Bluwstein and Canova 2016). Asset purchase programs provided lower yields and long-term interest rates but their long-term costs and fragility is unknown (Joyce et al., 2012). 
Key central banks coordinated their policies to multiply their impact (Neely, 2015) while they established FX swap lines with other central banks. However, the unwanted spillovers like flight to safety and FX turbulences affected a broader audience. That is the reason behind the formation of the three subsets:

- “QE appliers”: ECB, SR

- portfolio investment flows were balanced,

- $\mathrm{QE}$ describes their monetary policy best

- "Safe haven": SNB, DN

- portfolio investments had a positive balance, regardless of the negative interest premium

- negative interest policy, pegged FX regimes, FX swap lines

- “Visegrad-3 (V3)": CNB, NBP, MNB

- portfolio investments had a negative balance, regardless of the interest premium

- weaker fundamentals (for NBP and $\mathrm{MNB}$ ), slower initiation of monetary easing

This subsection summarised the method to capture the application of unconventional monetary instruments and defined the central bank subsets.

\subsection{The impact on foreign exchange rates}

Exchange rates should reflect the change in the macroeconomic fundamentals, but floating was combined with recessive volatility in the Central and Eastern European member states (Stavárek and Miglietti, 2015), while their trade is affected by these changes despite the hedging behaviour of the main exporter multinational companies (Simakova, 2016). The spillover effects of the central bank's actions have a general impact on capital markets through transmission channels (Jammazi et al., 2017; Csiki and Kiss, 2018). On the one hand, the relationship between foreign exchange and equity market rates can be viewed as the "international trade effect": the development of foreign exchange rates has a different effect on the competitiveness of export and import oriented companies and the overall corporate valuation (Aggarwal, 1981; Csiki - Kiss, 2018). On the other hand, stock prices influence the development of foreign exchange rates through the "portfolio balancing theory", which has been studied by many researchers on the effects of quantitative easing with different results per central bank (Thornton, 2014; Goldstein et al., 2018; Csiki and Kiss, 2018). A suggestion was also made through analysing the US markets that security purchase programs did not generate such effects and just shift the interest rate risk from bond holders to the taxpayers' shoulders; this theory, however, is refuted in the short-term (Kocherlakota, 2010; Thornton, 2014). 
Kiss, G. D. - Mészáros, M.: Exchange Rate Modeling under Unconventional Monetary Policy.

Following a decade of popularity of unconventional instruments, the effects on foreign exchange rates are still unclear. Kucharčuková et al. (2016) examined and compared the macroeconomic effects of the ECB's conventional and unconventional monetary policy to the euro area and its spillover to six EU countries outside the euro area. Through factor analysis and VAR models they found that the transmission mechanism of unconventional monetary policy in the euro area is quite different from the conventional tools. Their empirical results showed that outside the Eurozone, exchange rates responded faster and these responses turned for several countries in the opposite direction than when using conventional monetary instruments. Their conclusions on the real economy impact point towards slow and limited effects in both the examined groups (inside and outside the euro area), but inflation remains largely unaffected under the use of unorthodox instruments.

Inoue and Rossi (2019) analysed the effects of conventional and unconventional monetary policy especially on the exchange rates of the UK, Canada, Europe and Japan vis-à-vis the US dollar by using several different methods which resulted in less similar outcomes compared to the previously mentioned paper. They identified monetary policy shocks as shifts in the whole yield curve for the purpose of examining the impact of the changes in risk premia and changes in the agent's expectations of interest rates. Overall, based on their results the easing of the US monetary policy caused devaluation of the spot nominal exchange rate in both monetary policy periods, although the responses of exchange rate are significantly different depending on the changes in the people's expectations.

Adler and co-authors (2018) examined exchange rate dynamics under cooperative and self-oriented unconventional monetary policies through the two country DSGE model. On the one hand, their result showed that the use of unconventional instruments mitigated the depreciation in response to a negative shock. On the other hand, using the Nash equilibrium as a self-oriented case, they showed that central banks often apply unorthodox instruments and stabilised FX rates. Their study also found that where monetary policies apply ZLB, exchange rate controls were more frequent. In light of the above mentioned (and other) studies (Gourinchas and Rabanal, 2017; Neely, 2015; Rogers et al., 2018; Tillmann, 2016) on the given topic, we further investigate the effects of monetary developments on foreign exchange rates over the past decade.

\subsection{Theoretical model}

This paper aims to model the exchange rate movement under unconventional monetary policy. Function (1) defined the core model of the uncovered interest parity, while Function (2) augments it with the capital flows and the FX regime dummy. Function (4) needs to be added as well to capture all the non-policy rate related actions. However, it needs to be back tested (5) with macro variables like 
deviation from the targeted inflation $\left(\pi_{t}-\pi_{t}^{*}\right)$ and the output gap $\left(y_{t}-y_{t}^{*}\right)$ to compare their impacts (Model II.).

$$
\begin{gathered}
\Delta e_{t}=\omega+\alpha \Delta e_{t-1}+\beta_{1} \Delta\left(r_{t, d}-r_{t, f}\right)+\beta_{6} \Delta\left(\pi_{t}-\pi_{t}^{*}\right)+\beta_{7} \Delta\left(y_{t}-y_{t}^{*}\right) \\
+\beta_{3} \Delta \frac{L_{t}+S_{t}}{F X_{t}}+\beta_{4} \Delta C B B S_{t}+\beta_{5} D_{t}+\varepsilon_{t}
\end{gathered}
$$

Later, capital flows will be added, macro variables will be removed from the final model and a one quarter lag will be added to present a slower reaction (6) (Model III.).

$$
\begin{gathered}
\Delta e_{t}=\omega+\alpha \Delta e_{t-1}+\beta_{1} \Delta\left(r_{t-1, d}-r_{t-1, f}\right)+\beta_{2} \Delta P F_{t-1}+\beta_{3} \Delta \frac{L_{t-1}+S_{t-1}}{F X_{t-1}} \\
+\beta_{4} \Delta C B B S_{t-1}+\beta_{5} D_{t}+\varepsilon_{t}
\end{gathered}
$$

It can be assumed that the interest rate differential, capital inflow and regimedummy will all have a positive coefficient $\left(\beta_{1}>0, \beta_{2}>0, \beta_{5}>0\right)$ as the exchange rates appreciate. Meanwhile, excessive inflation, $\mathrm{QE}$ policies or balance sheet expansion leads to negative coefficients $\left(\beta_{6}<0, \beta_{3}<0, \beta_{4}<0\right)$.

\section{Data and Methodology}

This section presents the key characteristics of the data and summarises the methodological background of dynamic panel regressions.

Data (Tab. 2) was collected mainly from central bank databases, Eurostat and stooq.com, covering the 2007 Q1 - 2018 Q1 interval. All FX data used SDR as a denominator to overcome the possible biases of a USD denomination. Interest premia were calculated against German 10Y government bond yields, except for the Eurozone, which was calculated against US 10Y data. The $10 \mathrm{Y}$ maturity was preferred because it is less affected by liquidity turbulences or monetary policy. The output gap was calculated from the industrial production index against its HP filtered values, following Demir (2014) due to data availability and flexibility. First differences were used for all the variables and they were tested against the unit root by Im, Pesaran and Shin (2003) test. Descriptive statistics are available in Appendix 1. The possibility of multicollinearity was tested among variables for each country, but the LSFX and CBBS variables presented high $(\rho>0.55)$ correlation only in the Swiss and Polish cases (Appendix 2), making this fear unfounded. 
Kiss, G. D. - Mészáros, M.: Exchange Rate Modeling under Unconventional Monetary Policy.

\section{Tab. 2: Sources of the data}

\begin{tabular}{l|l}
\hline Variable (2007Q1-2018Q1) & Source \\
\hline FX rates (denominated in SDR) $e_{t}$ & stooq.com \\
10 year sovereign yield (10Y) $r_{t}$ & stooq.com \\
Output gap (industrial production index, HP filter) $\left(y_{t}-y_{t}^{*}\right)$ & OECD, Eurostat \\
Portfolio investments $P F_{t}$ & central banks, Eurostat \\
Deviation from inflation target $\left(\pi_{t}-\pi_{t}^{*}\right)$ & central banks, Eurostat \\
CBBS change (compared to 2007Q1 base) $C B B S_{t}$ & central banks (Balance sheet data) \\
LSFX $=(\mathrm{L}+\mathrm{S}) / \mathrm{FX}$ reserve & central banks (Balance sheet data) \\
FX regime dummy $D_{t}$ & central banks (Annual reports) \\
\hline
\end{tabular}

Source: Authorial computation

Securities and lending had a mixed importance in the central bank balance sheets, compared to the foreign exchange reserves (Fig. 1). Danish, Swiss and ECB's balance sheet was less FX reserve oriented, but the first two were pressurised by their inflating reserves later. Meanwhile, the ECB continued to expand their lending and securities programs, followed later by the Swedish and Hungarian central banks. The Polish and Czech national banks presented some bursts in the early years of the GFC.

\section{Fig. 1: LSFX ratio (lending and security accumulation to FX reserves)}

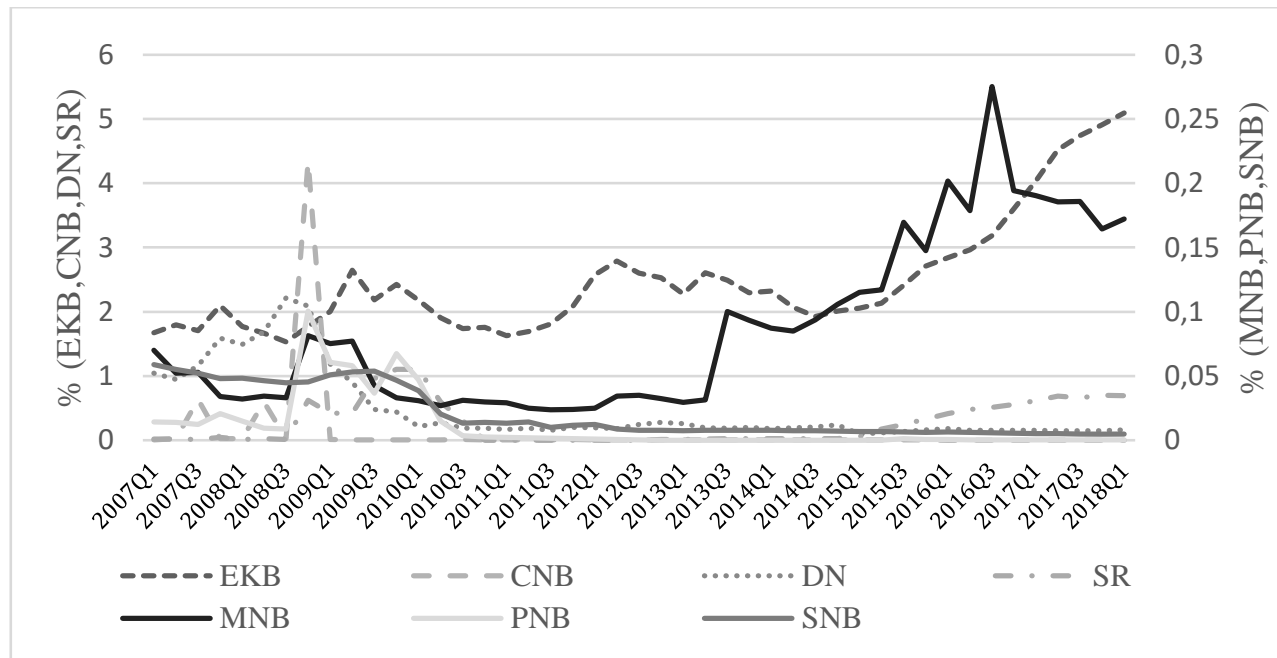

Source: Authorial computation, based on central bank data

The research was carried out with the one-step dynamic panel model, using the Gretl 2017d software. The reason for application of this methodology is that it fits the scope of our research topic perfectly, and there are several cases in the previous literature of studying the effects of monetary policy through panel regressions. For example, Hoffman and Takáts (2015) while using the fixed- 
effects panel regression in their paper found that US short- and long-term interest rates had a significant impact on the corresponding rates in other countries and these spillovers effects reflect in part policy spillovers. Eser and Schwaab (2016) inter alia concluded the yield impact of ECB's Securities Market Programme by dynamic panel regressions and found that these asset purchases reduced liquidity risk premia through making a sufficient contribution to ending the sovereign crisis. Panel regression can be used in respect of the databases in which the attributes of several units (in this case currencies and central banks) and several periods can be collected, while the specific attributes of the individual that are constant over the time need not be observable, because constant factors are dropped from the estimated equation. For numerous variables but a relatively short length and a higher potential for autocorrelation, the use of the dynamic panel model is accepted. The model (7) is based on an $\mathrm{AR}(1)$ process, where the $y_{i, t}$ resulting variable is explained with its own delayed values by means of the $\mu_{i}$ variable specific and $v_{i, t}$ zero mean value uncorrelated random errors (accepted for the fixed effect panel regressions) with $x_{i, t}$ explanatory variables (Blundell and Bond, 1998; Arellano and Bond, 1991):

$$
y_{i t}=\omega+\alpha y_{i t-1}+\beta x_{i t}+\mu_{i}+v_{i t}, \mathrm{i}=1, \ldots, \mathrm{n}, \mathrm{t}=1, \ldots, T_{i} .
$$

Under the following restrictions: $y_{i t}=\beta x_{i t}+f_{i}+\xi_{i t}$, where $\xi_{i t}=\alpha \xi_{i t-1}+v_{i}$ és $\mu_{i}=(1-\alpha) f_{i},|\alpha|<1$. The overidentification of the model was tested using the Sargan test, were $\mathrm{p}>0.05$ results pointed towards non-overidentified models.

\section{Results and Discussion}

This section summarises our results according to the Model I, II and III, where we tested these models by running dynamic panel regressions. Our results showed significant differences from the outcomes expected based on the results of previous literature measurements. The small and open economies around the Eurozone were heterogeneous enough to show regional differences in each subset, parallel to their past reactions. However, we should not forget that the entire sample can still be considered homogenous when it is compared to the rest of the world.

The first differences of variables were tested against the unit root with Im, Pesaran and Shin (2003) test and they followed the I(1) processes (Table 3).

First, we tested the Model I to capture both the motivation of the yield premium and the direction of the actual capital flow, as well as the short-term impact of the use of discretionary exchange rate measures on the tested sample. 
Kiss, G. D. - Mészáros, M.: Exchange Rate Modeling under Unconventional Monetary Policy.

Tab. 3: Im, Pesaran and Shin (2003) test results of unit root

\begin{tabular}{|c|c|c|}
\hline Panel & $\begin{array}{l}\text { t_bar statistic } \\
\text { W_bar statistic } \\
\text { P-value of the W_bar statistic } \\
\text { Z_bar statistic } \\
\text { P-value of the Z_bar statistic } \\
\text { t_bar_DF statistic } \\
\text { Z_bar_DF statistic } \\
\text { P-value of the Z_bar_DF statistic }\end{array}$ & $\begin{array}{r}-18.0945 \\
-51.0158 \\
0.0000 \\
-51.8262 \\
0.0000 \\
-17.6267 \\
-50.3622 \\
0.0000 \\
\end{array}$ \\
\hline Individual ADF test $p$ values & $\begin{array}{c}\Delta \mathrm{e}_{\mathrm{t}-1} \\
\Delta\left(\mathrm{r}_{\mathrm{t}, \mathrm{d}}-\mathrm{r}_{\mathrm{t}, \mathrm{f}}\right) \\
\Delta\left(\pi_{\mathrm{t}}-\pi_{\mathrm{t}}^{*}\right) \\
\Delta\left(\mathrm{y}_{\mathrm{t}}-\mathrm{y}_{\mathrm{t}}^{*}\right) \\
\Delta \mathrm{PF}_{\mathrm{t}} \\
\Delta \frac{\mathrm{L}_{\mathrm{t}}+\mathrm{S}_{\mathrm{t}}}{\mathrm{FX}_{\mathrm{t}}} \\
\Delta \mathrm{CBBS}_{\mathrm{t}}\end{array}$ & $\begin{array}{l}0.0100 \\
0.0100 \\
0.0100 \\
0.0100 \\
0.0100 \\
0.0100 \\
0.0100 \\
\end{array}$ \\
\hline
\end{tabular}

Notes: $\mathrm{p}<0.05$ values reject the unit root, lag $=1$, model contains constant

Source: Authorial computation

Tab. 4: Extended uncovered parity model (Model I)

\begin{tabular}{c|rrrrrrrr}
\hline \multirow{2}{*}{ Variables } & \multicolumn{2}{|c}{ entire sample } & \multicolumn{2}{c}{ DKK, CHF } & \multicolumn{2}{c}{ CZK, HUF, PLN } & \multicolumn{2}{c}{ EUR, SEK } \\
\cline { 2 - 9 } & coeff. & $\mathbf{P}$ & coeff. & $\mathbf{p}$ & coeff. & $\mathbf{p}$ & coeff. & $\mathbf{p}$ \\
\hline$\Delta e_{t-1}$ & 0.0497 & 0.3858 & -0.0676 & 0.0000 & -0.0208 & 0.0000 & 0.1004 & 0.0000 \\
const. & 0.0000 & 0.9862 & -0.0003 & 0.1497 & -0.0002 & 0.5201 & -0.0005 & 0.4973 \\
$\Delta\left(r_{t, d}-r_{t, f}\right)$ & 0.0823 & 0.0134 & 0.0007 & 0.0000 & 0.0134 & 0.2375 & 0.1121 & 0.3795 \\
$\Delta P F_{t}$ & -0.2016 & 0.4603 & 0.1136 & 0.0000 & -0.0124 & 0.9262 & -0.0773 & 0.5809 \\
$D_{t}$ & -0.0382 & 0.4062 & 0.0090 & 0.0000 & 0.0039 & 0.4227 & - & - \\
Sargan-test p & - & 0.1435 & - & 0.4888 & - & 0.296 & - & 0.3529 \\
\hline
\end{tabular}

Source: Authorial computation

As can be seen in Tab. 4 above, our results show that change in the premium of the 10-year bond yield caused strengthening of all the currencies within a quarter of the examined interval. Analysing the groups, only the "safe haven" central banks achieved significant results, where the yield premium, inflow of portfolio capital and also the exchange rate floor strengthened the Danish krone and the Swiss franc. For the "V3" and the "QE" groups, the analysis did not prove useful in the short term, because the economic areas served by these European central banks were too heterogeneous to lay down general regularities - although the fact of interest rate parity was an accepted formula in the pre-crisis literature. It is in line with the expected results, which is based on the fact that even years before the crisis, parity was not necessarily fulfilled.

All of these facts justified a deeper resolution, so we expressed the relationship between the FX rates and macroeconomy. It was also necessary to include the lending and bond market programs. This has been captured through the restructuring of the central bank assets (LSFX) and the aggregate increase in the 
CBBS. The Model II was still viable after the extension with the specific macro and central bank-related data as Table 5 suggests.

\section{Tab. 5: Uncovered parity model with macro and QE variables (Model II)}

\begin{tabular}{c|rrrrrrrr}
\hline \multirow{2}{*}{ variables } & \multicolumn{2}{|c}{ entire sample } & \multicolumn{2}{c}{ DKK, CHF } & \multicolumn{2}{c}{ CZK, HUF, PLN } & \multicolumn{2}{c}{ EUR, SEK } \\
\cline { 2 - 9 } & coeff. & $\mathbf{P}$ & coeff. & $\mathbf{p}$ & coeff. & p & coeff. & p \\
\hline$\Delta e_{t-1}$ & -0.0325 & 0.3723 & -0.0903 & 0.000 & -0.1291 & 0.0024 & -0.1347 & 0.1504 \\
const. & -0.0005 & 0.4739 & -0.0003 & 0.168 & -0.0004 & 0.3728 & -0.0018 & 0.3396 \\
$\Delta\left(r_{t, d}-r_{t, f}\right)$ & 0.1037 & 0.0860 & -0.0038 & 0.2543 & 0.0254 & 0.2377 & 0.1865 & 0.0016 \\
$\Delta\left(\pi_{t}-\pi_{t}^{*}\right)$ & 0.0104 & 0.4874 & 0.0043 & 0.234 & 0.0174 & 0.0523 & -0.0429 & 0.3287 \\
$\Delta\left(y_{t}-y_{t}^{*}\right)$ & 0.0244 & 0.0863 & -0.0007 & 0.246 & 0.0101 & 0.0838 & 0.0429 & 0.0232 \\
$\Delta L_{t}+S_{t}$ & 0.0205 & 0.442 & -0.0023 & 0.3929 & -0.0343 & 0.0000 & 0.5911 & 0.0000 \\
\hline$F X_{t}$ & -0.2674 & 0.0175 & -0.0031 & 0.0000 & 0.0243 & 0.0416 & -0.6571 & 0.0000 \\
$\Delta C B B S_{t}$ & 0.0002 & 0.9881 & 0.0082 & 0.0000 & -0.0019 & 0.2862 & - & - \\
$D_{t}$ & - & 0.2161 & - & 0.4017 & - & 0.4355 & - & 0.6138 \\
\hline Sargan-test p & & & & & & & &
\end{tabular}

Source: Authorial computation

Based on the Model II results, the change in the LSFX and the increase in the CBBS total proved to be a better explanatory variable than the interest rate premium. On the whole sample, the development of the CBBS total weakened all the currencies within a quarter during the period under review, but the rise in yield premium and output strengthened the currencies against the SDR. Analysing the groups, we found that under the unusual monetary policy of DN and SNB, currency peg appreciated the DKK and the CHF, while the change in the CBBS total had a depreciating effect on them. Loan programs and asset purchases of the "V3" strengthened the CZK, HUF and PLN against the SDR through the change in the CBBS of the central banks (unlike the outcome of the other groups), but the increasing ratio of LSFX caused their weakening, so the market reacted in a similar way as an interest rate cut - although we have to emphasise that in this case, the "V3" central bank balance sheets are heavily foreign exchange reserves and the size of their lending programs is minimal. In the case of "V3" central banks, the currency appreciation effect of inflation and the output gap can also be observed. In the group of ECB and SR quantitative easing played a major role, where the change in the ratio of the central bank securities and loans to foreign exchange reserves, like the yield premium and the output gap, had a strengthening effect on the EUR and the SEK during the research period. In contrast, the increase in the balance sheet total had a currency depreciation impactsimilarly to the "safe haven" and the full sample.

Model II was run repeatedly without the macro variables, which led to the fact that the balance sheet composition and balance sheet total indicators, which had previously been significant, remained significant with a similar sign and coefficient, and even the regression of the group of "safe haven" central banks resulted in more significant explanatory variables than the previous outcome. 
Kiss, G. D. - Mészáros, M.: Exchange Rate Modeling under Unconventional Monetary Policy.

Based on these outcomes, we considered the deviation from the inflation target and the output gap to be omitted from the final model.

During the previous investigations, we have separately verified that the foreign exchange rate is affected by the interest parity supplemented by the portfolio investments and the change in the structure and volume of the central bank balance sheet. In the final Model III test, these two areas were analysed together so that the characteristics of each central bank group could subsequently be identified.

\section{Tab. 6: Extended uncovered parity model with QE variables (Model III)}

\begin{tabular}{|c|c|c|c|c|c|c|c|c|}
\hline \multirow{2}{*}{ variables } & \multicolumn{2}{|c|}{ entire sample } & \multicolumn{2}{|c|}{ DKK, CHF } & \multicolumn{2}{|c|}{ CZK, HUF, PLN } & \multicolumn{2}{|c|}{ EUR, SEK } \\
\hline & coeff. & $\mathbf{p}$ & coeff. & $\mathbf{p}$ & coeff. & $\mathbf{p}$ & coeff. & $\mathbf{p}$ \\
\hline$\Delta \mathrm{e}_{\mathrm{t}-1}$ & -0.0247 & 0.6804 & -0.1062 & 0.0000 & -0.1297 & 0.0000 & -0.2752 & 0.0000 \\
\hline const. & -0.0001 & 0.8729 & -0.0004 & 0.1174 & -0.0003 & 0.5517 & -0.0012 & 0.4912 \\
\hline$\Delta\left(r_{t, d}-r_{t, f}\right)$ & 0.0941 & 0.0035 & -0.0006 & 0.0005 & 0.0055 & 0.6144 & 0.1891 & 0.0533 \\
\hline$\Delta\left(\mathrm{r}_{\mathrm{t}-1, \mathrm{~d}}-\mathrm{r}_{\mathrm{t}-1, \mathrm{f}}\right)$ & -0.0138 & 0.6742 & 0.0082 & 0.0856 & 0.0098 & 0.0000 & 0.0494 & 0.0002 \\
\hline$\Delta \frac{\mathrm{L}_{\mathrm{t}}+\mathrm{S}_{\mathrm{t}}}{\mathrm{FX}_{\mathrm{t}}}$ & -0.0158 & 0.6253 & 0.0018 & 0.0000 & -0.0520 & 0.0000 & 0.5421 & 0.1076 \\
\hline$\Delta \frac{\mathrm{L}_{\mathrm{t}-1}+\mathrm{S}_{\mathrm{t}-1}}{\mathrm{FX}_{\mathrm{t}-1}}$ & -0.0583 & 0.0708 & 0.0038 & 00 & -0.0233 & 0.0000 & 0.0893 & 0.0000 \\
\hline$\Delta \mathrm{PF}_{\mathrm{t}}$ & 0.0343 & 0.8958 & 0.1401 & 0.0000 & -0.3016 & 0.0383 & 0.0775 & 0.4725 \\
\hline$\Delta \mathrm{PF}_{\mathrm{t}-1}$ & 0.0076 & 0.9763 & 0.1776 & 0.0000 & 0.2820 & 0.1792 & 0.0036 & 0.9283 \\
\hline$\Delta \mathrm{CBBS}_{\mathrm{t}}$ & -0.2773 & 0.0000 & -0.0176 & 0.0000 & 0.0067 & 0.0973 & -0.6992 & 0.0000 \\
\hline$\Delta \mathrm{CBBS}_{\mathrm{t}-1}$ & -0.0599 & 0.2366 & -0.0062 & 0.0000 & 0.0053 & 0.1996 & -0.2544 & 0.0000 \\
\hline $\mathrm{D}_{\mathrm{t}}$ & -0.0087 & 0.9306 & 0.0249 & 0.0000 & -0.0411 & 0.0000 & - & \\
\hline$D_{t-1}$ & 0.0171 & 0.8652 & -0.0141 & 0.0000 & 0.0471 & 0.0000 & - & \\
\hline Sargan-test $p$ & - & 0.2739 & - & 0.452 & - & 0.2882 & - & 0.3598 \\
\hline
\end{tabular}

Source: Authorial computation

As we can see from the Model III results in Table 4, increase in the interest rate premia had a purely appreciable effect on the value of the currencies both at the level of the whole sample and at the level of the central banks. In addition, with alternate signs (derived from the different profiles of the analysed currencies) only the short-term effects of the change in the variables representing unconventional monetary policy was detectable on the whole sample and its classifications.

On the model of "safe haven" central banks, the overall Model III proved to be significant; so we can say that the asset purchases, credit programs and the Swiss exchange rate peg has strengthened DKK and CHF, but the growth of the CBBS has weakened them. In this group, and in the case of the "V3", the importance of portfolio capital investments which has strengthened DKK and CHF but weakened the currencies of "V3", play an important role in the exchange rate fluctuations, especially in view of the fact that these central banks had faced alternating capital inflows during the period under investigation. In the Visegrad countries, unconventional instruments spread much later and were less involved in the balance sheet structure reorganisation. However, within the quarterly outlook it can be seen that the other two groups of central banks had an adverse effect on the exchange rate fluctuations. In addition, it should be noted that among the "V3", 
the exchange rate ceiling applied in Czechia supported the exchange rate of the other two currencies. In the case of "QE appliers", the currency weakening effect of the change in the CBBS and the weak currency strengthening effect of asset purchases were measured.

Reflecting on the pre-formulated expectations, the following comments can be made: the $\beta_{1}$ parameter of the interest parity was significant in all the groups and the sample as a whole, but this was not the most significant variable. Portfolio capital flow proved to be much more important in 2 groups ("safe haven","V3"), but the $\beta_{2}$ parameter sign varied quarterly. The impact of inflation growth could only be measured in the case of the central banks of the "V3: countries, where the currencies strengthened against the expectations. The lending programs, asset purchase programs, complements the interest rate policy, so we expected $\beta_{3}<0$ parameters, which were met in the "V3" group and the whole sample, but as a difference groups of the "safe haven" and the "QE appliers" had positive values. The increase in the balance sheet total may result from an increase in the FX reserves revalued as a result of the currency depreciation (MNB, NBP), but also from the expansion due to the use of unconventional instruments (ECB) - thus the value of the parameter $\beta_{4}$ was expected to be similar to $\beta_{3}$ which matched surprisingly only with the regression of the whole sample, but with the opposite sign for the sub-samples of the central groups.

\section{Conclusion}

In our study, we examined the effects of unconventional monetary policy on foreign exchange rates on a consolidated example of European non-Eurozone central banks and the European Central Bank.

The main question of our research was to find out whether the use of ZLB and unconventional instruments had an impact on changes in the foreign exchange rates. In the case of the 7 central banks which are the subject of our analysis, we could observe a more intense central bank role in line with the features of diverse financial institutions of different countries, and in the case of most of the unconventional central banks examined, there was a quick transition to the active side regulation of the monetary toolbar, so the preference of direct instruments.

We divided the central banks into 3 groups based on the preferences of using nonstandard assets, and depending on the relationship between portfolio investment and risk premium in their respective countries, followed by dynamic panel regressions.

Overall, our results confirm that foreign exchange rates were significantly influenced in the short term by the central banks' introduction of unorthodox monetary policy instruments over the past decade, such as liquidity-providing 
Kiss, G. D. - Mészáros, M.: Exchange Rate Modeling under Unconventional Monetary Policy.

credit programs and asset purchases. Taking these factors into account may be important when considering further monetary policy measures by central banks.

In the course of potential further research, answering several possible questions may be of interest, e.g.: did the use of other unorthodox tools have an effect on the exchange rates in addition to the examined non-conventional tools? In terms of analysis from another perspective, it may also be interesting to analyse the spillover effects of the ECB's non-conventional steps and to model the possible consequences of the current non-conventional exit.

\section{References}

Acharya, V. V., Eisert, T., Eufinger, C., Hirsch, C., 2019. Whatever it takes: The real effects of unconventional monetary policy. The Review of Financial Studies 32, 9, 3366-3411. DOI: 10.1093/rfs/hhz005.

Aggarwal, R., 1981. Exchange Rates and Stock Prices: A Study of U.S. Capital Market under Floating Exchange Rates. Akron Business and Economic Review 3, 9, 7-12.

Arellano, M., Bond, S., 1991. Some tests of specification for panel data: Monte Carlo evidence and an application to employment equations. The review of economic studies 58, 2, 277-297. DOI: 10.2307/2297968.

Bekaert, G., Engstrom, E., Xing, Y., 2009. Risk, uncertainty, and asset prices. Journal of Financial Economics 91, 1, 59-82. DOI: 10.1016/j.jfineco.2008.01.005.

Bernanke, B. S., Reinhart, V. R., 2004. Conducting monetary policy at very low short-term interest rates. American Economic Review 94, 2, 85-90. DOI: $10.1257 / 0002828041302118$.

Blundell, R., Bond, S., 1998. Initial conditions and moment restrictions in dynamic panel data models. Journal of econometrics 87, 1, 115-143. DOI: 10.1016/S0304-4076(98)00009-8.

Bluwstein, K., Canova, F., 2016. Beggar-thy-neighbor? The international effects of ECB unconventional monetary policy measures. International Journal of Central Banking 12, 3, 69-120.

Hofmann, B., Takáts, E., 2015. International monetary spillovers. BIS Quarterly Review September. Available from: <https://ssrn.com/abstract=2661596>. [6 September 2019].

Calvo, G. A., Reinhart, C. M., 2002. Fear of Floating. The Quarterly Journal of Economics 117, 2, 379-408. DOI: 10.1162/003355302753650274.

Csiki, M., Kiss, G. D., 2018. Tőkepiaci fertőzések a visegrádi országok részvénypiacain a Heckman-féle szelekciós modell alapján. Hitelintézeti Szemle 17, 4, 23-52. DOI: 10.25201/HSZ.17.4.2352. 
Csortos, O., Lehmann, K., Szalai, Z., 2014. Az előretekintő iránymutatás elméleti megfontolásai és gyakorlati tapasztalatai. MNB Szemle 9, 12, 45-55.

Czeczeli, V., 2017. Az EKB mennyiségi lazítási programjának tapasztalatai Európai tükör 20, 1, 103-126.

Demir, İ., 2014. Monetary policy responses to the exchange rate: Empirical evidence from the ECB. Economic Modelling 39, 4, 63-70. DOI: 10.1016/j.econmod.2014.02.024.

Eser, F., Schwaab, B., 2016. Evaluating the impact of unconventional monetary policy measures: Empirical evidence from the ECB' s Securities Markets Programme. Journal of Financial Economics 119, 1, 147-167. DOI: 10.1016/j.jfineco.2015.06.003.

Gambacorta, L., Hofmann, B., Peersman, G., 2014. The effectiveness of unconventional monetary policy at the zero lower bound: A cross-country analysis. Journal of Money, Credit and Banking 46, 4, 615-642. DOI: 10.1111/jmcb.12119.

Goldstein, I., Witmer, J., Yang, J., 2018. Following the money: Evidence for the portfolio balance channel of quantitative easing. Bank of Canada Staff Working Paper No. 2018-33. Bank of Canada.

Habib, M. M., Stracca, L., 2012. Getting beyond carry trade: What makes a safe haven currency? Journal of International Economics 87, 1, 50-64. DOI: 10.1016/j.jinteco.2011.12.005.

Herger, N., 2016. Panel Data Models and the Uncovered Interest Parity Condition: The Role of Two-Way Unobserved Components. International Journal of Finance \& Economics 21, 3, 294-310. DOI: 10.1002/ijfe.1552.

Horváth, D., Szini, R., 2015. The safety trap - the financial market and macroeconomic consequences of the scarcity of low-risk assets. Financial and Economic Review 14, 1, 111-138.

Im, K. S., Pesaran, M. H., Shin, Y., 2003. Testing for unit roots in heterogeneous panels. Journal of econometrics 115, 1, 53-74. DOI: 10.1016/S03044076(03)00092-7.

Inoue, A., Rossi, B., 2019. The effects of conventional and unconventional monetary policy on exchange rates. Journal of International Economics 118, 419447. DOI: 10.1016/j.jinteco.2019.01.015.

Jammazi, R., Ferrer, R., Jareño, F., Hammoudeh, S. M., 2017. Main driving factors of the interest rate-stock market Granger causality. International Review of Financial Analysis, 52, 260-280. DOI: 10.1016/j.irfa.2017.07.008. 
Kiss, G. D. - Mészáros, M.: Exchange Rate Modeling under Unconventional Monetary Policy.

Joyce, M., Miles, D., Scott, A., Vayanos, D., 2012. Quantitative easing and unconventional monetary policy-an introduction. The Economic Journal, 122, 564, F271-F288. DOI: 10.1111/j.1468-0297.2012.02551.x.

Kiss, Á., Szilágyi, K., 2014. Miért más ez a válság, mint a többi? Az adósságleépítés szerepe a nagy recesszióban. Közgazdasági szemle 61, 9, 949974.

Kocherlakota, N., 2010. Economic Outlook and the Current Tools of Monetary Policy. Speech at the European Economics and Financial Centre, London, England. Available from: <minneapolisfed.org/news_events/pres/speech_displ ay.cfm?id=4555/>. [30 August 2019].

Kool, C. J., Thornton, D. L., 2015. How effective is central bank forward guidance? Federal Reserve Bank of St. Louis, Working Paper N. 2012-063A. Available from: <research.stlouisfed.org/wp/2012/2012-063.pdf.>. [3 September 2019].

Krekó, J., Balogh, Cs., Lehmann, K., Mátrai, R., Pulai, Gy., Vonnák, B., 2012. Nemkonvencionális jegybanki eszközök alkalmazásának nemzetközi tapasztalatai és hazai lehetőségei. MNB tanulmányok, 100. háttértanulmány.

Kucharčuková, O. B., Claeys, P., Vašíček, B., 2016. Spillover of the ECB's monetary policy outside the euro area: How different is conventional from unconventional policy? Journal of Policy Modeling 38, 2, 199-225. DOI: 10.1016/j.jpolmod.2016.02.002.

Lewis, V., Roth, M., 2015. The Financial Market Effects of the ECB's Balance Sheet Policies, September 24, 2015. DOI: 10.2139/ssrn.2671763.

Magyar Nemzeti Bank (MNB), 2012. Monetáris politikai fogalomtár. Magyar Nemzeti Bank, Budapest, Hungary. Available from: <mnb.hu/letoltes/monetarispolitikai-fogalomtar-2012-hu.pdf>. [26 August 2019].

Neely, C. J., 2015. Unconventional monetary policy had large international effects. Journal of Banking \& Finance 52, 101-111. DOI: 10.1016/j.jbankfin.2014.11.019.

Pelle, A., Végh, M. Z. 2019. How has the Eurozone Changed Since its Inception? Public Finance Quarterly 64, 1, 127-145.

Ranaldo, A., Söderlind, P., 2010. Safe haven currencies. Review of finance 14, 3, 385-407. DOI: 10.1093/rof/rfq007.

Rogers, J. H., Scotti, C., Wright, J. H., 2018. Unconventional monetary policy and international risk premia. Journal of Money, Credit and Banking 50, 8, 18271850. DOI: $10.1111 / \mathrm{jmcb} .12511$. 
Šimáková, J., 2016. Cointegration Approach to the Estimation of the Long-Run Relations between Exchange Rates and Trade Balances in Visegrad Countries. Financial Assets and Investing 7, 3, 37-57. DOI: 10.5817/FAI2016-3-3.

Singer, M., 2015. Unconventional Policies of Central Banks in Europe in the Period of Disinflation. 4th Annual Research Conference, 23 April 2015, Skopje, FYR Macedonia. Available from: <cnb.cz/export/sites/cnb/en/public/.galleries/ media_service/conferences/speeches/download/singer_20150423_skopje.pdf $>$. [5 March 2019].

Stavárek, D., Miglietti, C., 2015. Effective Exchange Rates in Central and Eastern European Countries: Cyclicality and Relationship with Macroeconomic Fundamentals. Review of Economic Perspectives 15, 2, 157-177. DOI: 10.1515/revecp-2015-0015.

Svensson, L. E., 2000. Open-economy inflation targeting. Journal of international economics 50, 1, 155-183. DOI: 10.1016/S0022-1996(98)00078-6.

Taylor, J. B., 1993. Discretion versus policy rules in practice. Carnegie-Rochester conference series on public policy 39, 195-214. North-Holland, DOI: 10.1016/0167-2231(93)90009-L.

Taylor, J. B., 2001. The role of the exchange rate in monetary-policy rules. American Economic Review 91, 2, 263-267. DOI: 10.1257/aer.91.2.263.

Thornton, D. L., 2014. QE: is there a portfolio balance effect? Federal Reserve Bank of St. Louis Review 96, 1, 55-72. DOI: 10.20955/r.96.55-72.

Tillmann, P., 2016. Unconventional monetary policy and the spillovers to emerging markets. Journal of International Money and Finance 66, 136-156. DOI: 10.1016/j.jimonfin.2015.12.010. 
Kiss, G. D. - Mészáros, M.: Exchange Rate Modeling under Unconventional Monetary Policy.

Appendix 1: Descriptive statistics of data

\begin{tabular}{|c|c|c|c|c|c|c|c|c|}
\hline & & $\Delta e_{t}$ & $\Delta\left(r_{t, d}-r_{t, f}\right)$ & $\Delta\left(\pi_{t}-\pi_{t}^{*}\right)$ & $\Delta\left(y_{t}-y_{t}^{*}\right)$ & $\Delta P F_{t}$ & $\Delta \frac{L_{t}+S_{t}}{F X_{t}}$ & $\overline{\Delta C B B S_{t}}$ \\
\hline \multirow{7}{*}{ Ф્ } & Swiss & 0.00 & -0.02 & -0.01 & -0.03 & 0.01 & 0.08 & 0.07 \\
\hline & Czech & 0.00 & 0.02 & 0.01 & -0.02 & 0.00 & 0.00 & 0.07 \\
\hline & Danish & -0.01 & -0.01 & -0.04 & -0.01 & 0.00 & -0.02 & 0.01 \\
\hline & Eurozone & 0.00 & -0.03 & -0.16 & 0.03 & 0.00 & 0.00 & 0.02 \\
\hline & Hungarian & 0.00 & 0.03 & -0.04 & 0.00 & 0.00 & 0.00 & 0.04 \\
\hline & Polish & -0.03 & 0.00 & 0.01 & -0.01 & 0.00 & 0.02 & 0.08 \\
\hline & Swedish & 0.00 & 0.01 & 0.01 & 0.14 & 0.00 & 0.00 & 0.15 \\
\hline \multirow{7}{*}{ 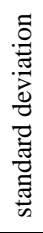 } & Swiss & 0.02 & 0.47 & 0.53 & 1.23 & 0.11 & 0.25 & 0.16 \\
\hline & Czech & 0.17 & 0.28 & 0.95 & 1.19 & 0.01 & 0.95 & 0.23 \\
\hline & Danish & 0.32 & 0.24 & 0.68 & 1.16 & 0.01 & 0.20 & 0.17 \\
\hline & Eurozone & 0.02 & 0.57 & 0.97 & 1.53 & 0.01 & 0.03 & 0.17 \\
\hline & Hungarian & 0.01 & 0.21 & 0.67 & 0.78 & 0.01 & 0.02 & 0.12 \\
\hline & Polish & 0.37 & 0.27 & 0.62 & 1.61 & 0.02 & 0.17 & 0.40 \\
\hline & Swedish & 0.02 & 0.28 & 0.65 & 1.10 & 0.04 & 0.00 & 0.31 \\
\hline \multirow{7}{*}{ 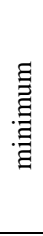 } & Swiss & -0.06 & -0.86 & -2.00 & -4.12 & -0.21 & -0.46 & -0.32 \\
\hline & Czech & -0.31 & -0.84 & -3.00 & -3.65 & -0.01 & -4.33 & -0.10 \\
\hline & Danish & -0.82 & -0.66 & -2.00 & -3.02 & -0.03 & -0.90 & -0.31 \\
\hline & Eurozone & -0.06 & -1.70 & -2.80 & -4.68 & -0.02 & -0.09 & -0.32 \\
\hline & Hungarian & -0.05 & -0.42 & -1.80 & -2.07 & -0.03 & -0.04 & -0.20 \\
\hline & Polish & -1.08 & -0.65 & -2.10 & -4.99 & -0.04 & -0.50 & -0.99 \\
\hline & Swedish & -0.04 & -0.74 & -2.50 & -2.54 & -0.14 & -0.02 & -0.34 \\
\hline \multirow{7}{*}{ 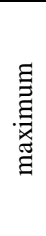 } & Swiss & 0.05 & 1.07 & 1.20 & 2.88 & 0.39 & 0.65 & 0.45 \\
\hline & Czech & 0.36 & 0.76 & 2.50 & 2.33 & 0.01 & 4.32 & 1.42 \\
\hline & Danish & 0.67 & 0.72 & 1.30 & 2.63 & 0.02 & 0.54 & 0.70 \\
\hline & Eurozone & 0.05 & 1.65 & 1.40 & 2.71 & 0.02 & 0.10 & 0.54 \\
\hline & Hungarian & 0.02 & 0.45 & 1.60 & 1.96 & 0.03 & 0.09 & 0.37 \\
\hline & Polish & 0.89 & 0.65 & 1.40 & 3.74 & 0.06 & 0.61 & 2.19 \\
\hline & Swedish & 0.06 & 0.54 & 1.30 & 3.16 & 0.09 & 0.01 & 1.17 \\
\hline
\end{tabular}

Source: Authorial computation 
European Financial and Accounting Journal, 2019, vol.14, no. 3, pp. 05-24.

Appendix 2: Cross-sectional correlations among input variables

\begin{tabular}{|c|c|c|c|c|c|c|c|c|}
\hline & $\Delta e_{t}$ & $\Delta\left(r_{t, d}-r_{t, f}\right)$ & $\Delta\left(\pi_{t}-\pi_{t}^{*}\right)$ & $\Delta\left(y_{t}-y_{t}^{*}\right)$ & $\Delta P F_{t}$ & $\Delta \frac{L_{t}+S_{t}}{F X_{t}}$ & & $\overline{C B B S_{t}}$ \\
\hline \multirow{7}{*}{$\sum_{n}^{n}}$. & 1.00 & -0.11 & 0.13 & 0.12 & 0.09 & 0.08 & -0.18 & $\Delta e_{t}$ \\
\hline & -0.11 & 1.00 & -0.10 & -0.03 & 0.02 & -0.17 & 0.32 & $\Delta\left(r_{t, d}-r_{t, f}\right)$ \\
\hline & 0.13 & -0.10 & 1.00 & 0.67 & 0.17 & -0.05 & 0.00 & $\Delta\left(\pi_{t}-\pi_{t}^{*}\right)$ \\
\hline & 0.12 & -0.03 & 0.67 & 1.00 & 0.18 & -0.26 & -0.24 & $\Delta\left(y_{t}-y_{t}^{*}\right)$ \\
\hline & 0.09 & 0.02 & 0.17 & 0.18 & 1.00 & -0.03 & 0.13 & $\triangle P F$ \\
\hline & 0.08 & -0.17 & -0.05 & -0.26 & -0.03 & 1.00 & 0.59 & $\Delta \frac{L_{t}+S_{t}}{F X_{t}}$ \\
\hline & -0.18 & 0.32 & 0.00 & -0.24 & 0.13 & 0.59 & 1.00 & $\triangle C B B S_{t}$ \\
\hline \multirow{7}{*}{$\begin{array}{l}\stackrel{2}{0} \\
\stackrel{0}{3}\end{array}$} & 1.00 & 0.19 & 0.22 & 0.28 & -0.46 & -0.02 & -0.16 & $\Delta e_{t}$ \\
\hline & 0.19 & 1.00 & -0.31 & -0.11 & 0.03 & 0.00 & -0.12 & $\Delta\left(r_{t, d}-r_{t, f}\right)$ \\
\hline & 0.22 & -0.31 & 1.00 & 0.47 & 0.00 & -0.20 & 0.11 & $\Delta\left(\pi_{t}-\pi_{t}^{*}\right)$ \\
\hline & 0.28 & -0.11 & 0.47 & 1.00 & -0.01 & -0.14 & 0.10 & $\Delta\left(y_{t}-y_{t}^{*}\right)$ \\
\hline & -0.46 & 0.03 & 0.00 & -0.01 & 1.00 & -0.03 & 0.43 & $\triangle P F$ \\
\hline & -0.02 & 0.00 & -0.20 & -0.14 & -0.03 & 1.00 & 0.03 & $\Delta \frac{L_{t}+S_{t}}{F X_{t}}$ \\
\hline & -0.16 & -0.12 & 0.11 & 0.10 & 0.43 & 0.03 & 1.00 & $\triangle C B B S_{t}$ \\
\hline \multirow{7}{*}{ 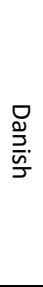 } & 1.00 & 0.37 & 0.13 & -0.01 & -0.25 & 0.02 & -0.33 & $\Delta e_{t}$ \\
\hline & 0.37 & 1.00 & -0.21 & -0.14 & -0.27 & 0.12 & -0.19 & $\Delta\left(r_{t, d}-r_{t, f}\right)$ \\
\hline & 0.13 & -0.21 & 1.00 & 0.53 & 0.01 & 0.34 & -0.09 & $\Delta\left(\pi_{t}-\pi_{t}^{*}\right)$ \\
\hline & -0.01 & -0.14 & 0.53 & 1.00 & 0.10 & 0.32 & -0.01 & $\Delta\left(y_{t}-y_{t}^{*}\right)$ \\
\hline & -0.25 & -0.27 & 0.01 & 0.10 & 1.00 & 0.00 & 0.18 & $\triangle P F$ \\
\hline & 0.02 & 0.12 & 0.34 & 0.32 & 0.00 & 1.00 & 0.23 & $\Delta \frac{L_{t}+S_{t}}{F X_{t}}$ \\
\hline & -0.33 & -0.19 & -0.09 & -0.01 & 0.18 & 0.23 & 1.00 & $\triangle C B B S_{t}$ \\
\hline \multirow{7}{*}{$\begin{array}{l}\text { m } \\
\stackrel{0}{0} \\
\text { N } \\
\stackrel{0}{0}\end{array}$} & 1.00 & -0.40 & 0.23 & 0.22 & -0.41 & -0.01 & -0.74 & $\Delta e_{t}$ \\
\hline & -0.40 & 1.00 & -0.19 & -0.37 & 0.18 & 0.24 & 0.36 & $\Delta\left(r_{t, d}-r_{t, f}\right)$ \\
\hline & 0.23 & -0.19 & 1.00 & 0.12 & -0.16 & -0.23 & -0.40 & $\Delta\left(\pi_{t}-\pi_{t}^{*}\right)$ \\
\hline & 0.22 & -0.37 & 0.12 & 1.00 & -0.33 & -0.19 & -0.18 & $\Delta\left(y_{t}-y_{t}^{*}\right)$ \\
\hline & -0.41 & 0.18 & -0.16 & -0.33 & 1.00 & 0.02 & 0.26 & $\Delta P F$ \\
\hline & -0.01 & 0.24 & -0.23 & -0.19 & 0.02 & 1.00 & 0.10 & $\Delta \frac{L_{t}+S_{t}}{F X_{t}}$ \\
\hline & -0.74 & 0.36 & -0.40 & -0.18 & 0.26 & 0.10 & 1.00 & $\triangle C B B S_{t}$ \\
\hline \multirow{7}{*}{ 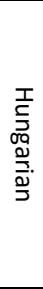 } & 1.00 & 0.01 & 0.13 & 0.27 & -0.71 & -0.25 & -0.49 & $\Delta e_{t}$ \\
\hline & 0.01 & 1.00 & 0.30 & -0.19 & -0.01 & 0.34 & 0.05 & $\Delta\left(r_{t, d}-r_{t, f}\right)$ \\
\hline & 0.13 & 0.30 & 1.00 & 0.05 & -0.10 & -0.09 & -0.01 & $\Delta\left(\pi_{t}-\pi_{t}^{*}\right)$ \\
\hline & 0.27 & -0.19 & 0.05 & 1.00 & -0.14 & -0.38 & 0.06 & $\Delta\left(y_{t}-y_{t}^{*}\right)$ \\
\hline & -0.71 & -0.01 & -0.10 & -0.14 & 1.00 & 0.19 & 0.55 & $\Delta P F$ \\
\hline & -0.25 & 0.34 & -0.09 & -0.38 & 0.19 & 1.00 & -0.05 & $\Delta \frac{L_{t}+S_{t}}{F X_{t}}$ \\
\hline & -0.49 & 0.05 & -0.01 & 0.06 & 0.55 & -0.05 & 1.00 & $\triangle C B B S_{t}$ \\
\hline \multirow{6}{*}{$\begin{array}{l}\frac{D}{\bar{J}} \\
\stackrel{\bar{v}}{\bar{s}}\end{array}$} & 1.00 & 0.37 & 0.19 & 0.43 & -0.11 & -0.11 & -0.58 & $\Delta e_{t}$ \\
\hline & 0.37 & 1.00 & 0.21 & 0.04 & 0.12 & 0.02 & -0.15 & $\Delta\left(r_{t, d}-r_{t, f}\right)$ \\
\hline & 0.19 & 0.21 & 1.00 & 0.29 & 0.25 & -0.18 & -0.44 & $\Delta\left(\pi_{t}-\pi_{t}^{*}\right)$ \\
\hline & 0.43 & 0.04 & 0.29 & 1.00 & 0.07 & -0.37 & -0.55 & $\Delta\left(y_{t}-y_{t}^{*}\right)$ \\
\hline & -0.11 & 0.12 & 0.25 & 0.07 & 1.00 & 0.00 & -0.05 & $\triangle P F$ \\
\hline & -0.11 & 0.02 & -0.18 & -0.37 & 0.00 & 1.00 & 0.75 & $\Delta \frac{L_{t}+S_{t}}{F X_{t}}$ \\
\hline
\end{tabular}


Kiss, G. D. - Mészáros, M.: Exchange Rate Modeling under Unconventional Monetary Policy.

\begin{tabular}{|c|c|c|c|c|c|c|c|c|}
\hline & \multirow{2}{*}{$\begin{array}{l}\Delta e_{t} \\
-0.58\end{array}$} & \multirow{2}{*}{$\begin{array}{r}\Delta\left(r_{t, d}-r_{t, f}\right) \\
-0.15\end{array}$} & \multirow{2}{*}{$\begin{array}{r}\Delta\left(\pi_{t}-\pi_{t}^{*}\right) \\
-0.44\end{array}$} & \multirow{2}{*}{$\begin{array}{r}\Delta\left(y_{t}-y_{t}^{*}\right) \\
-0.55\end{array}$} & \multirow{2}{*}{$\begin{array}{l}\Delta P F_{t} \\
-0.05\end{array}$} & \multirow{2}{*}{$\frac{\Delta \frac{L_{t}+S_{t}}{F X_{t}}}{0.75}$} & \multicolumn{2}{|c|}{$\triangle C B B S_{t}$} \\
\hline & & & & & & & 1.00 & $\Delta C B B S_{t}$ \\
\hline \multirow{7}{*}{ 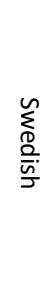 } & 1.00 & 0.13 & -0.01 & -0.01 & -0.49 & 0.08 & -0.43 & $\Delta e_{t}$ \\
\hline & 0.13 & 1.00 & 0.12 & 0.04 & -0.37 & 0.29 & -0.22 & $\Delta\left(r_{t, d}-r_{t, f}\right)$ \\
\hline & -0.01 & 0.12 & 1.00 & 0.47 & -0.13 & -0.16 & -0.16 & $\Delta\left(\pi_{t}-\pi_{t}^{*}\right)$ \\
\hline & -0.01 & 0.04 & 0.47 & 1.00 & -0.04 & -0.33 & -0.16 & $\Delta\left(y_{t}-y_{t}^{*}\right)$ \\
\hline & -0.49 & -0.37 & -0.13 & -0.04 & 1.00 & -0.22 & 0.45 & $\triangle P F$ \\
\hline & 0.08 & 0.29 & -0.16 & -0.33 & -0.22 & 1.00 & -0.14 & $\Delta \frac{L_{t}+S_{t}}{F X_{t}}$ \\
\hline & -0.43 & -0.22 & -0.16 & -0.16 & 0.45 & -0.14 & 1.00 & $\triangle C B B S_{t}$ \\
\hline
\end{tabular}

Source: Authorial computation 